\title{
Invited comment to: Minimal modulation of the host immune response to small intestinal submucosa by mesenchymal stem cells from the amniotic fluid. F. Lesagne, S. Pranpanus, F.M. Bosisio, M. Jacobs, S. Ospitalieri, J. Toelen, J. Deprest
}

\author{
A. H. Petter-Puchner ${ }^{1}$
}

Received: 3 September 2017 / Accepted: 22 October 2017 / Published online: 16 November 2017

(c) Springer-Verlag France SAS 2017

Hernia surgery and research is now on the verge of integrating reconstructive medicine and tissue engineering in large scale [1]. One important aspect is the quest for implementing stem cell therapies (SCT). The main questions in this context are the complex regulatory issues, related costs and the identification of potential benefits for the patient. The market for these innovations is highly competitive and "sophisticated". Bearing these circumstances in mind, it does not come as surprise that SCT is a seemingly everlasting promise in an apparently always deferred future. Studies like the one by Prof. Deprest et al. are, therefore, absolutely mandatory to show possible directions and indications for SCT in hernia repair [2]. It is futile at this point of time to get into a dispute whether small intestine submucosa is a feasible material for future applications or if there are pros and cons of the retrieval process of the cell lines used in this specific trial. Of course I am pleased that amniotic fluid is gaining wider attention as a source for SCT, as our team in Vienna has followed a similar approach and published on it several years ago [3].

Experimental and basic research will be needed to show us the door through which we might enter a new era in hernia and abdominal wall repair. There is no doubt that SCT represent a versatile key.

This comment provides me with the possibility to express my strong belief that any attempt (and I emphasize that this certainly was not the intention of the study by Prof. Deprest

This comment refers to the article available at doi:10.1007/ s10029-017-1635-6.

A. H. Petter-Puchner

alexander.petter@trauma.lbg.ac.at

1 Ludwig Boltzmann Institute for experimental and Clinical Traumatology, Austrian Cluster for Tissue Regeneration, Donaueschingenstrasse 13, 1200 Vienna, Austria et al.) to "pimp" some problematic scaffolds", e.g. collagen matrices, by so elegantly re-introducing stem cell therapies to hernia repair, will come to a dead end [4].

\section{Compliance with ethical standards}

Conflict of interest The author does report no conflict of interest.

Ethical approval No approval was required for this work (comment).

Human and animal rights This comment does not include any data derived from humans or animals.

Informed consent No consent needed to be obtained and therefore does not apply to this work.

\section{References}

1. Zhang Y, Zhou Y, Zhou X, Zhao B, Chai J, Liu H, Zheng Y, Wang J, Wang Y, Zhao Y (2017) Preparation of a nano- and micro-fibrous decellularized scaffold seeded with autologous mesenchymal stem cells for inguinal hernia repair. Int J Nanomed 21(12):1441-1452

2. Lesage F, Pranpanus S, Bosisio FM, Jacobs M, Ospitalieri S, Toelen J, Deprest J (2017) Minimal modulation of the host immune response to SIS matrix implants by mesenchymal stem cells from the amniotic fluid. Hernia. https://doi.org/10.1007/ s10029-017-1635-6

3. Petter-Puchner AH, Fortelny RH, Mika K, Hennerbichler S, Redl H, Gabriel C (2011) Human vital amniotic membrane reduces adhesions in experimental intraperitoneal onlay mesh repair. SurgEndosc. 25(7):2125-2131. https://doi.org/10.1007/s00464-0101507-y (Epub 2010 Dec 10)

4. Petter-Puchner AH, Fortelny RH, Gruber-Blum S, Redl H, Dietz U (2015) The future of stem cell therapy in hernia and abdominal wall repair. Hernia 19(1):25-31. https://doi.org/10.1007/s10029014-1288-7 (Epub 2014 Aug 14. Review) 